\title{
GCKR mutations in Japanese families with clustered type 2 diabetes.
}

\section{AUTHOR(S):}

Tanaka, Daisuke; Nagashima, Kazuaki; Sasaki, Mayumi; Yamada, Chizumi; Funakoshi, Shogo; Akitomo, Kimiyo; Takenaka, Katsunobu; Harada, Kouji; Koizumi, Akio; Inagaki, Nobuya

\section{CITATION:}

Tanaka, Daisuke ... [et al]. GCKR mutations in Japanese families with clustered type 2 diabetes.. Molecular genetics and metabolism 2011, 102(4): 453-460

\section{ISSUE DATE:}

2011-04

URL:

http://hdl.handle.net/2433/139535

\section{RIGHT:}

(c) 2010 Elsevier Inc.; この論文は出版社版でありません。引用の際には 出版社版をご確認ご利用ください。; This is not the published version. Please cite only the published version. 
$1 \quad G C K R$ mutations in Japanese families with clustered type 2 diabetes

2

3 Daisuke Tanaka ${ }^{a}$, Kazuaki Nagashima ${ }^{a}$, Mayumi Sasaki ${ }^{a}$, Chizumi Yamada $^{a}$, Shogo

4 Funakoshi $^{\mathrm{a}}$, Kimiyo Akitomo ${ }^{\mathrm{a}}$, Katsunobu Takenaka ${ }^{\mathrm{b}}$, Kouji Harada ${ }^{\mathrm{c}}$, Akio Koizumi ${ }^{\mathrm{c}}$, and

$5 \quad$ Nobuya Inagaki ${ }^{a}$

6

$7 \quad{ }^{a}$ Department of Diabetes and Clinical Nutrition, Graduate School of Medicine, Kyoto

8 University, Kyoto, Japan

$9 \quad{ }^{\mathrm{b}}$ Takayama Red Cross Hospital, Gifu, Japan

$10{ }^{\mathrm{c}}$ Department of Health and Environmental Sciences, Graduate School of Medicine, Kyoto

11 University, Kyoto, Japan

12

13 Corresponding Author:

14 Nobuya Inagaki

15 Department of Diabetes and Clinical Nutrition,

16 Graduate School of Medicine, Kyoto University

1754 Shogoin-Kawahara-cho, Sakyo-ku, Kyoto, 606-8507, Japan

18 Telephone: $+81-75-751-3562$

19 Fax: +81-75-771-6601

20 E-mail: inagaki@metab.kuhp.kyoto-u.ac.jp

21

22 Running Title: GCKR mutations in Japanese families 
24 Abstract:

25 Objective

26 The aim was to investigate the genetic background of familial clustering of type 2 diabetes.

27 Subjects and Methods

28 We recruited Japanese families with a 3-generation history of diabetes. Genome-wide linkage analysis was performed assuming an autosomal dominant model. Genes in the linkage region were computationally prioritized using Endeavour. We sequenced the candidate genes, and the frequencies of detected nucleotide changes were then examined in normoglycemic controls.

\section{Results}

To exclude known genetic factors, we sequenced 6 maturity onset diabetes of the young (MODY) genes in 10 familial cases. Because we detected a MODY3 mutation HNF1A R583G in one case, we excluded this case from further investigation. Linkage analysis revealed a significant linkage region on 2p25-22 (LOD score $=3.47$ ) for 4 families. The 23.6-Mb linkage region contained 106 genes. Those genes were scored by computational prioritization. Eleven genes, i.e., top $10 \%$ of 106 genes, were selected and considered them as primary candidates. Considering their functions, we eliminated 3 well characterized genes and finally sequenced 8 genes. GCKR ranked highly in the computational prioritization. Mutations (minor allele frequency less than 1\%) in exons and the promoter of $G C K R$ were found in index cases of the families ( 3 of 18 alleles) more frequently than in controls ( 0 of 36 alleles, $\mathrm{P}=0.033)$. In one pedigree with 9 affected members, the mutation $G C K R$ g.6859C $>\mathrm{G}$ was concordant with affection status. No mutation in other 7 genes that ranked highly in the prioritization was concordant with affection status in families.

\section{Conclusions}


48 We propose that $G C K R$ is a susceptibility gene in Japanese families with clustered diabetes.

49 The family based approach seems to be complementary with a large population study.

50

51 Keywords: Genetic susceptibility, Linkage analysis, MODY, HNF1A, GCKR

52

53 Abbreviations:

54 GAD: Glutamic acid decarboxylase

55 GCKR: Glucokinase regulator

56 HLOD: Heterogeneity logarithm of the odds

57 HNF4 $\alpha$ : Hepatocyte Nuclear Factor $4 \alpha$

58 LOD: Logarithm of the odds

59 MAF: Minor allele frequency

60 MODY: Maturity onset diabetes of the young

61 RFLP: Restriction fragment length polymorphism

62 SNP: Single nucleotide polymorphism

63 


\section{Introduction}

65

66

67

68

69

70

The national survey in 2007 reported that 8.9 million people suffer from diabetes in Japan [1]. Most of these have type 2 diabetes, and the number of such patients has increased continuously. Both genetic and environmental factors play important roles in the pathogenesis of type 2 diabetes [2].

To elucidate the genetic factors underlying the pathogenesis of type 2 diabetes in the Japanese population, several genome-wide linkage analyses in Japanese sib-pairs have been performed [3-5]. Linkage to $11 \mathrm{p} 13-\mathrm{p} 12$ is consistently implicated in these studies [5]. Recent successes with genome-wide association analyses in the Japanese population have revealed a susceptibility variant in $K C N Q 1$ located at $11 \mathrm{p} 15.5[6,7]$, a locus not far from the region suggested in linkage analyses. The association of susceptibility loci including TCF7L2, $C D K A L 1, C D K N 2 A / B, I G F 2 B P 2, S L C 30 A 8$, and $H H E X$ with diabetes has been established in Caucasian populations and replicated in the Japanese population [8]. However, the loci identified in association studies have uniformly small effect sizes, and can explain only a small portion of the genetic background of diabetes in the Japanese population. Approaches other than sib-pair linkage analyses and association analyses may therefore be required to elucidate a greater aspect of the genetic background of type 2 diabetes.

In the present study, we used a family-based approach, because high degrees of familial clustering can raise the relative risk and provide better insight to novel loci of larger effect size [9]. Familial clustering of diabetes is well known, the typical example being MODY [10]. On the other hand, in most families in Japan, familial clustering cannot be attributed to mutations of the 6 known MODY genes [10], and genetic predisposition in such families has not been ascertained. 
88 We recruited families having a 3-generation history of diabetes and performed

89 genome-wide linkage analysis. We selected candidate genes in the linked chromosomal

90 region and searched for rare and common nucleotide changes the genes in familial cases and

91 unaffected controls.

92 
2. Material and Methods

94

\subsection{Families and Additional Index Cases}

96

We recruited patients from collaborating hospitals in Japan who had diabetes with a

3-generation family history, which is suggestive of autosomal dominant mode of inheritance

[11]. If $\geq 2$ family members with diabetes were alive and donated DNA, the families were regarded as suitable subjects for the present study. Families including members with positive GAD (Glutamic Acid Decarboxylase) antibody were excluded from the study. Four families met these criteria and were included in the linkage analysis (Figure 1). Affected status of the participants was determined in two ways. First, if participants had been diagnosed with diabetes and treated with oral hypoglycemic agents or insulin injection, they were regarded as affected. Second, if participants had not been treated with oral hypoglycemic agents or insulin injection, they underwent $\mathrm{HbA1c}\left(\right.$ Hemoglobin $\mathrm{A}_{1 \mathrm{c}}$ ) measurement for screening of impaired glucose tolerance. The value for HbA1c is estimated as an NGSP (US National Glycohemoglobin Standardization Program) equivalent value (\%) calculated by the formula $\operatorname{HbA1c}(\%)=\operatorname{HbA1c}(\mathrm{JDS}$, Japanese Diabetes Society) $(\%)+0.4 \%$, considering the relational expression of $\mathrm{HbA1c}(\mathrm{JDS})(\%)$ measured by the previous Japanese standard substance and measurement methods and HbA1c (NGSP) [12]. If their HbA1c levels were $\geq 6.0 \%$, they were also regarded as affected. HbA1c $\geq 6.0 \%$ is the level defined as possible diabetes mellitus in the 2007 survey of the Ministry of Labor, Health and Welfare of Japan [1]. In addition to these subjects, 6 index cases from other families with a 3-generation history of diabetes were included in the study (Supplementary Figure 1). In these families, although we confirmed the affected status of some of the family members, DNA samples were available 
117 only for the index cases but not for other family members. Together with the 4 index cases

118 from the families included in the linkage analysis, a total of 10 unrelated cases with a

119 3-generation history of diabetes were available for DNA sequencing. The clinical features of 120 family members and additional index cases are shown in Table 1.

121

\subsection{Normoglycemic controls}

An annual medical check-up program was performed in Nyukawa district of Takayama

City, Japan. Nine-hundred ninety local residents (430 men, 560 women) were recruited in the program and consented to donate their DNA. From 2002 to 2007, participants underwent physical examination and blood tests including fasting plasma glucose and $\mathrm{HbA} 1 \mathrm{c}$ every year.

We selected normoglycemic controls from the participants in the cohort. Subjects defined as normoglycemic controls had the following characteristics: HbA1c $<6.0 \%$ and fasting plasma glucose $<5.5 \mathrm{mmol} / 1$ during 5-year follow-up span, and age $\geq 55$. The number of subjects that satisfied the definition was 206 (81 men, 125 women).

\subsection{Genotyping Family Members}

Genomic DNA was extracted from blood samples with a QIAamp DNA Blood Mini Kit

136 (Qiagen Inc). PCR amplification from genomic DNA was performed with fluorescence-labeled (6-FAM, HEX, NED) and tailed primers. PCR primers to analyze microsatellite markers comprised an approximately 10cM human index map (ABI Prism Linkage Mapping Set Version 2.5: 382 markers for 22 autosomes), and other microsatellite fine markers were designed according to information from the UniSTS map. PCR reactions 
were carried out in $7.5 \mu$ with 50 ng genomic DNA, using AmpliTaq Gold DNA Polymerase (Applied Biosystems) in a 2-step amplification program. DNA fragments were analyzed on an Applied Biosystems 3130 Genetic Analyzer. Genotyping errors and inconsistent relationships were checked with the use of GENEHUNTER (version 2.1) software [13]. If the results of genotyping were missed or ambiguous, we treated them as an unknown genotype in the linkage analysis. The rate of genotyping failure was $0.057 \%(7 / 11842)$.

\subsection{Linkage and Haplotype Analyses}

Both affected and unaffected family members were included in the linkage analysis. Participants with $\mathrm{HbA} 1 \mathrm{c}$ level $<6.0 \%$ were considered as unaffected if the age was $\geq 55$ and as unknown if the age was $<55$, considering the assumed age-dependent penetrance of diabetes. The purpose of including members assigned as unknown was to increase the accuracy of haplotype estimation in affected members, although inclusion did not increase the statistical power. Multipoint parametric analyses for autosomes were run using GENEHUNTER assuming an autosomal dominant model [13]. Because locus heterogeneity could be associated with diabetes, LOD (log of the odds) score and HLOD (heterogeneity LOD) score were calculated. The disease allele frequency was set at 0.00001 and a phenocopy frequency of 0.00001 was assumed. Population allele frequencies for each microsatellite marker were assigned equal portions for individual alleles. We used a 2-stage design: first, all chromosomal regions were screened by genotyping at an approximately 10cM density (screening), and the regions where LOD scores were highest were considered potentially interesting. Second, these regions were further finely mapped at approximately 1to 2-cM densities (fine mapping). Regions where LOD scores were above 3.3, a level 
corresponding to genome-wide significance [9], were considered as linkage regions. Haplotypes were constructed with the GENEHUNTER program.

\subsection{Prioritization of Candidate Genes}

The 23.6-Mb linkage region on chromosome 2p25-22 contained 106 genes annotated in Ensemble genome browser (www.ensembl.org). The genes were computationally prioritized using Endeavour (www.esat.kuleuven.be/endeavour/) [14]. We selected 6 MODY genes (HNF4A, GCK, HNF1A, PDXI, HNF1B, and NEURODI) as training genes because a dominant mode of inheritance was assumed in the highly clustered families in linkage analysis. We adopted all databases available in Endeavour, which prioritized glucokinase regulator $(G C K R)$ at the first rank.

\subsection{Sequencing}

We directly sequenced the coding exons of 6 MODY genes (HNF4A, GCK, HNF1A, PDX1, $H N F 1 B$, and $N E U R O D 1)$ in the 10 index cases. We sequenced GCKR including all exons found in the National Center for Biotechnology Information (NCBI) Evidence Viewer (www.ncbi.nlm.nih.gov) and the 2-kb promoter region in the index cases from families and in control subjects. We also selected other 7 genes that are highly prioritized within the 11th rank $(10.3 \%)$ in the linkage region using Endeavour excluding 3 genes with known metabolic functions unrelated to glucose metabolism (Supplementary Table 1). We sequenced the entire coding exons of the 7 genes in the index cases from families included in the linkage analysis. Forward and reverse PCR primers for each exon were selected in an intronic sequence $50 \mathrm{bp}$ 
away from the intron/exon boundaries and primers to amplify the $G C K R$ promoter region were also selected. Sequencing primer data for $G C K R$ is shown in Supplementary Table 2. PCR products were run on $2 \%$ agarose gel, and the appropriate bands were excised and then purified with the use of the QIAquick Gel Extraction Kit (Qiagen). Sequencing results were analyzed on an ABI Prism 3130 Avant DNA sequencer (Applied Biosystems). Any nucleotide changes identified in sequencing were searched for SNPs (single nucleotide polymorphisms) in the dbSNP database (www.ncbi.nlm.nih.gov/SNP/).

\subsection{Genotyping SNPs}

If minor allele frequencies (MAF) of nucleotide changes identified in sequencing were unregistered in the HapMap JPT database on dbSNP as of April 2010 and the minor allele appeared in $<2$ of all subjects, MAF was determined in the expanded population. We defined mutation as $\mathrm{MAF}<1 \%$ [15]. To determine whether each nucleotide change was a mutation or not, we genotyped 105 normoglycemic controls randomly selected from the cohort (Supplementary Table 3), because genotyping of 210 normal chromosomes is necessary to achieve $80 \%$ power to detect a polymorphism present in $1 \%$ of the population [16]. The PCR-RFLP (restriction fragment length polymorphism) method for HNF1A R583G, GCKR g.-689G>A, GCKR g.-299G>A, GCKR E252K and FOSL2 R198H and Taqman method for GCKR g.6859C $>\mathrm{G}$ were used.

\subsection{Statistical analysis}

$$
\text { Frequencies of mutations }(\mathrm{MAF}<1 \%) \text { and common nucleotide changes }(\mathrm{MAF} \geq 1 \%)
$$


213 identified in GCKR sequencing in the index cases and in normoglycemic controls were

214 compared by the Fisher exact test with SAS software (version 8.2).

215

216 2.9. Ethics

217

218 The methods used in this study were approved by the Ethics Committee of the Kyoto

219 University Institutional Review Board, and approved written informed consent was obtained 220 from each participant.

221 


\section{Results}

\subsection{Characteristics of Family Members}

Four families with a 3-generation history of diabetes were enrolled in this study (Figure 1,

Table 1). Every family included no less than 1 member that had been diagnosed with diabetes

with diabetes. Thirteen out of the 16 members with diabetes were lean $(\mathrm{BMI}<25)$. Six members were treated with insulin and another 10 members were treated with oral hypoglycemic agents. Twelve family members who had not been diagnosed with diabetes underwent $\mathrm{HbA} 1 \mathrm{c}$ measurement and 3 of them had $\mathrm{HbAlc}$ level $\geq 6.0 \%$. These 3 members had already been diagnosed with impaired glucose tolerance before this study and were included as affected members in the study.

3.2. Exclusion of MODY gene mutations in the index cases

For the 10 index cases, we performed direct sequencing in entire coding exons of the MODY genes. The detected missense SNPs were HNF1A I27L (rs1169288), HNF1A S487N (rs2464196), HNF1A R583G, and HNF4A T117I (rs1800961) (Supplementary Table 4). HNF1A R583G is a mutation that is reported to cause MODY [17], thus we excluded the carrier of the mutation (additional index case \#6, Table 1) from further investigation. HNF1A I27L and HNF1A S487N are common in the general population (MAF=0.386 and 0.341 , respectively in HapMap-JPT). HNF4A T117I was associated with late-onset type 2 diabetes but it was not the cause of MODY in a previous report [18]. 
A total of 30 members (19 affected members) from 4 families were included in the linkage analysis, assuming an autosomal dominant model. The genome-wide linkage results in the screening are shown in Figure 2. Regions of potential interest by multipoint LOD and HLOD scores were observed on chromosomes $2 \mathrm{p} 24$ and $7 \mathrm{q} 34$. After fine mapping, 2p25-22 was revealed to be a significant linkage region (Figure 3, LOD and HLOD=3.47) while the region on $7 \mathrm{q} 34$ was discarded. The size of the region with positive HLOD score was $23.6 \mathrm{Mb}$ (D2S2199-D2S2230). In the region, a haplotype segregated in affected and unaffected members in the pedigrees 1,2 , and 3 , but not in the pedigree 4 .

\subsection{Candidate Genes}

We searched candidate genes in the implicated linkage region by applying a gene prioritization approach implemented in Endeavour software. We selected 6 MODY genes as training genes. The 2 top-ranked genes were glucokinase regulatory protein $(G C K R)$ and nuclear receptor coactivator 1 (NCOA1). GCKR ranked high in prioritization using gene-gene interaction databases (first rank in 5 out of 7 interaction databases), mainly because the interaction of glucokinase and glucokinase regulatory protein has been demonstrated in previous studies $[19,20]$. NCOAl also ranked high in prioritization using gene-gene interaction databases (second rank in 2 out of 7 interaction databases), because nuclear receptor coactivator 1 has been reported to interact with HNF4 $\alpha$ (Hepatocyte Nuclear Factor 
within the 11th rank (10.3\% of annotated genes) were considered as candidate genes except 3 genes with well-characterized metabolic functions unrelated to glucose metabolism (Supplementary Table 1).

\subsection{Direct Sequencing in GCKR and other candidate genes}

We performed direct sequencing in exons and the 2-kb promoter region of $G C K R$. Sequencing was performed in 9 index cases from families and in 18 normoglycemic controls in parallel. The 18 control subjects were randomly selected from 206 normoglycemic controls (Supplementary Table 3). Detected sequence changes in the 9 index cases and 18 controls are shown in Table 2. Five nucleotide changes (g.-959 Insertion AATGTTG, E66E, E77G, g.9709G>A, and L446P) were considered to be common variants, because the minor allele was found in not less than 2 subjects out of a total of 27 case and control subjects. To determine whether or not each of the other nucleotide changes (g.-689G>A, g.-299G>A, E252K and g. $6859 \mathrm{C}>\mathrm{G})$ was a mutation $(\mathrm{MAF}<1 \%)$, genotyping was performed in a total of 105 normoglycemic controls. g.-689G $>$ A, g.-299G $>$ A and g.6859C $>$ G were not detected in the 105 controls, and were regarded as mutations, while E252K was detected in 4 controls out of $105(\mathrm{MAF}=1.9 \%)$ and was regarded as a common change. The number of alleles having mutations was thus significantly larger in the index cases from families than in the controls (3/18 alleles vs. $0 / 36$ alleles, $\mathrm{P}=0.033$, Fisher exact test).

We performed direct sequencing in the entire coding exons of other 7 candidate genes in index cases from 4 families. One misssense mutation FOSL2 R198H (MAF=0.004 in normoglycemic controls) was detected. No other mutations were detected in other 6 genes (Supplementary Table 5). 
3.6. Segregation of the mutations with the Phenotype in Pedigrees

296

297 In index cases from the 4 families included in the linkage analysis, 3 sequence changes of 298 GCKR were detected (g.-959 Insertion AATGTTG, g.6859C > G and L446P). We tested the segregation of $G C K R$ g. $6859 \mathrm{C}>\mathrm{G}$, a mutation detected in pedigree 3, with the phenotype in the pedigree. Another 2 changes (GCKR g.-959 Insertion AATGTG and GCKR L446P) were commonly detected in controls (3/36 alleles and 11/36 alleles respectively). In pedigree 3 , GCKR g.6859C>G was detected in all 9 affected members, but was not detected in the unaffected member (II-7). We performed linkage analysis and haplotype construction in 2p25-22 using the GCKR g.6859 genotype together with the microsatellite markers. The parametric multipoint LOD score for pedigree 3 was 2.67 at the GCKR g.6859 locus. Haplotype analysis revealed that all affected individuals in pedigree 3 shared a disease haplotype within D2S2199-D2S2230, which includes GCKR g.6859G (Figure 4). In pedigree

3, another sequence change, GCKR L446P, was detected, but GCKR L446P did not co-segregate with the disease. Haplotype analysis revealed that the minor allele of $G C K R$ L446P (g.11169C) resided on a different haplotype than GCKR g.6859G in affected subjects III-11, 12, 13, 14 (Figure 4).

We tested the segregation of FOSL2 R198H, a mutation detected in pedigree 4, with the phenotype. FOSL2 R198H was detected in 2 affected subjects (II-2, II-22) but not detected in one subject (II-1). 


\section{Discussion and Conclusions}

Recent progress in genome-wide association studies has identified tens of type 2 diabetes susceptibility genes. Even so, only a small portion of the genetic background of diabetes has been explained in the Japanese population. The loci identified in association studies have only very small effect sizes. We hypothesized that rare disease variants with larger effect sizes remain to be discovered that may explain a greater part of the genetic background. Family-based linkage study is an important alternative for the identification of rare disease variants. Indeed, studies with large families with highly clustered diabetes have revealed important mutations involved in MODY and other dominantly inherited diabetes, including a KCNJ11 mutation [22]. We therefore recruited families with a 3-generation history of diabetes. The validity of our strategy was strengthened by the fact that one case out of the 10 index cases recruited in our study carried a previously reported rare disease variant $H N F 1 A$ R583G.

Our family analysis revealed a significant linkage region on chromosome $2 \mathrm{p} 25-22$ that has not been reported in previous Japanese sib-pair analyses [3-5]. Because our approach was based on a higher degree of familial clustering than sib-pair analyses, the linkage region suggested in the present study might well go undetected in sib-pair analyses that include an admixture of sib-pairs with both low and high degrees of familial clustering. In the present study, we conducted a computational approach targeting the linkage region on chromosome $2 \mathrm{p} 25-22$. One hundred and six known genes were present in this linkage region. Prioritization of the candidate gene was possible by integrating the information available from multiple publicly available databases [14]. GCKR and other 7 gens ranked high in the prioritization, and were selected as candidate genes. 
340 GCKR regulates glucokinase (GCK), the first glycolytic enzyme, in liver. GCKR-null mice

341 exhibit elevated postprandial glucose [19]. Adenoviral-mediated overexpression of GCKR in 342 mouse liver increases GCK activity and lowers fasting blood glucose. It was suggested that 343 GCKR, a competitive inhibitor of GCK activity, also has a paradoxical role in extending 344 GCK half-life by stabilizing the enzyme [20]. If so, diminished expression of GCKR in human might cause decreased GCK activity in liver and lead to impaired liver glucose uptake, which suggests the GCKR mutation as a possible cause of the disease in linked families.

We sequenced entire exons and the $2-\mathrm{kb}$ promoter region of $G C K R$ in 9 index 3-generation cases and in 18 control subjects. The rare variants were significantly more frequent in index cases from families than in control subjects. In addition, exonic rare variant g.6859C $>\mathrm{G}$ in pedigree 3 , which was not detected in 105 control subjects, was clearly segregated in all 9 affected members in pedigree 3. Previous reports have shown the association of common GCKR variants with fasting plasma glucose, glucose level after glucose challenge, and diabetes risk in various ethnic groups [23-30]. In Japanese population, a common variant GCKR rs780094 is associated with fasting glucose and diabetes risk [27, 30]. Our family study suggests the effect of rare GCKR variants on diabetes susceptibility that has not been revealed by previous association studies. A recent study has shown the excess of rare GCKR variants in individuals with hypertriglyceridemia [31], which supports our idea that rare GCKR mutations also affect the diabetes susceptibility.

On the other hand, the only one mutation in other 7 highly prioritized genes was FOSL2 $\mathrm{R} 198 \mathrm{H}$ and it did not co-segregate with the phenotype in the pedigree. Therefore, we tentatively eliminate the possibility that these genes are involved in familial clustering of diabetes patients in the current pedigrees. 
364 Only 4 families could be included in the linkage analysis because we limited the cohort to

365 3-generation families with $\geq 2$ affected members who donated DNA. Further efforts to recruit

366 large families are needed to narrow down the linkage region. Second, because the GCKR

367 g.6859C $>\mathrm{G}$ mutation was in a non-coding exon, confirming the relevance of the mutation as

368 the cause of the disease is difficult. Investigation of the effect of the mutation in human liver,

369 where GCKR is predominantly expressed [32], is required, but liver specimens of family

370 members are currently unavailable. Although we tried to determine the mRNA level in

371 peripheral blood of family members, GCKR mRNA was only barely detectable with the

372 RT-PCR method (data not shown), so comparison of the GCKR mRNA level between

373 affected and unaffected members was not possible. We speculate that the g.6859C $>\mathrm{G}$ mutatin might affect GCKR function in liver through mRNA transcription or splicing processes [33]. GCKR g.-689G>A and g.-299G >A mutations located in the promoter also might affect the expression of GCKR, but TRANSFAC database [34] expected no binding sites of transcription factors at the two promoter mutations.

378 In conclusion, with systematic investigation we propose that $G C K R$ is a susceptibility gene in Japanese families with clustered diabetes. A family-based approach may be a promising strategy to elucidate the complex genetic background of common diseases including type 2 diabetes. 


\section{Acknowledgements}

384 This work was supported by a grant for Research on Human Genome Tailor-Made from the 385 Ministry of Health, Labor, and Welfare of Japan, a grant for Intractable Disease Research 386 Program from the Ministry of Health, Labor, and Welfare of Japan, Scientific Research 387 Grants from the Ministry of Education, Culture, Sports, Science, and Technology of Japan, 388 and a grant from Core Research for Evolutional Science and Technology (CREST) of Japan 389 Science and Technology Cooperation, and by Kyoto University Global COE Program 390 "Center for Frontier Medicine". 
391

392

393

394

395

396

397

398

399

400

401

402

403

404

405

406

407

408

409

410

411

412

413

414

\section{References}

[1] Ministry of Health, Labor and Welfare of Japan, Health and Nutrition Survey. 2007 (2008)

[2] S. O'Rahilly, I. Barroso, N.J. Wareham, Genetic factors in type 2 diabetes: the end of the beginning? Science 307 (2005) 370-373

[3] Y. Mori, S. Otabe, C. Dina, K. Yasuda, C. Populaire, C. Lecoeur, V. Vatin, E. Durand, K. Hara, T. Okada, K. Tobe, P. Boutin, T. Kadowaki, P. Froguel, Genome-wide search for type 2 diabetes in Japanese affected sib-pairs confirms susceptibility genes on 3q, 15q, and 20q and identifies two new candidate Loci on 7p and 11p. Diabetes 51 (2002) 1247-1255

[4] N. Iwasaki, N.J. Cox, Y.Q. Wang, P.E. Schwarz, G.I. Bell, M. Honda, M. Imura, M. Ogata, M. Saito, N. Kamatani, Y. Iwamoto, Mapping genes influencing type 2 diabetes risk and BMI in Japanese subjects. Diabetes 52 (2003) 209-213

[5] H. Nawata, S. Shirasawa, N. Nakashima, E. Araki, J. Hashiguchi, S. Miyake, T. Yamauchi, K. Hamaguchi, H. Yoshimatsu, H. Takeda, H. Fukushima, T. Sasahara, K. Yamaguchi, N. Sonoda, T. Sonoda, M. Matsumoto, Y. Tanaka, H. Sugimoto, H. Tsubouchi, T. Inoguchi, T. Yanase, N. Wake, K. Narazaki, T. Eto, F. Umeda, M. Nakazaki, J. Ono, T. Asano, Y. Ito, S. Akazawa, I. Hazegawa, N. Takasu, M. Shinohara, T. Nishikawa, S. Nagafuchi, T. Okeda, K. Eguchi, M. Iwase, M. Ishikawa, M. Aoki, N. Keicho, N. Kato, K. Yasuda, K. Yamamoto, T. Sasazuki, Genome-wide linkage analysis of type 2 diabetes mellitus reconfirms the susceptibility locus on 11p13-p12 in Japanese. J Hum Genet 49 (2004) 629-634

[6] K. Yasuda, K. Miyake, Y. Horikawa, K. Hara, H. Osawa, H. Furuta, Y. Hirota, H. Mori, A. Jonsson, Y. Sato, K. Yamagata, Y. Hinokio, H.Y. Wang, T. Tanahashi, N. Nakamura, Y. Oka, N. Iwasaki, Y. Iwamoto, Y. Yamada, Y. Seino, H. Maegawa, A. Kashiwagi, J. Takeda, E. 
415

416

417

418

419

420

421

422

423

424

425

426

427

428

429

430

431

432

433

434

435

436

437

438

Maeda, H.D. Shin, Y.M. Cho, K.S. Park, H.K. Lee, M.C. Ng, R.C. Ma, W.Y. So, J.C. Chan, V. Lyssenko, T. Tuomi, P. Nilsson, L. Groop, N. Kamatani, A. Sekine, Y. Nakamura, K. Yamamoto, T. Yoshida, K. Tokunaga, M. Itakura, H. Makino, K. Nanjo, T. Kadowaki, M. Kasuga, Variants in KCNQ1 are associated with susceptibility to type 2 diabetes mellitus. Nat Genet 40 (2008) 1092-1097

[7] H. Unoki, A. Takahashi, T. Kawaguchi, K. Hara, M. Horikoshi, G. Andersen, D.P. Ng, J. Holmkvist, K. Borch-Johnsen, T. Jorgensen, A. Sandbaek, T. Lauritzen, T. Hansen, S. Nurbaya, T. Tsunoda, M. Kubo, T. Babazono, H. Hirose, M. Hayashi, Y. Iwamoto, A. Kashiwagi, K. Kaku, R. Kawamori, E.S. Tai, O. Pedersen, N. Kamatani, T. Kadowaki, R. Kikkawa, Y. Nakamura, S. Maeda, SNPs in KCNQ1 are associated with susceptibility to type 2 diabetes in East Asian and European populations. Nat Genet 40 (2008) 1098-1102.

[8] K. Miyake, W. Yang, K. Hara, K. Yasuda, Y. Horikawa, H. Osawa, H. Furuta, M.C. Ng, Y. Hirota, H. Mori, K. Ido, K. Yamagata, Y. Hinokio, Y. Oka, N. Iwasaki, Y. Iwamoto, Y. Yamada, Y. Seino, H. Maegawa, A. Kashiwagi, H.Y. Wang, T. Tanahashi, N. Nakamura, J. Takeda, E. Maeda, K. Yamamoto, K. Tokunaga, R.C. Ma, W.Y. So, J.C. Chan, N. Kamatani, H. Makino, K. Nanjo, T. Kadowaki, M. Kasuga, Construction of a prediction model for type 2 diabetes mellitus in the Japanese population based on 11 genes with strong evidence of the association. J Hum Genet 54 (2009) 236-241

[9] E.S. Lander, N.J. Schork, Genetic dissection of complex traits. Science 265 (1994) $2037-2048$

[10] K. Yamagata, Regulation of pancreatic beta-cell function by the HNF transcription network: lessons from maturity-onset diabetes of the young (MODY). Endocr J 50 (2003) 491-499

[11] Y. Mineharu, K. Takenaka, H. Yamakawa, K. Inoue, H. Ikeda, K.I. Kikuta, Y. Takagi, K. 
439 Nozaki, N. Hashimoto, A. Koizumi, Inheritance pattern of familial moyamoya disease:

440 autosomal dominant mode and genomic imprinting. J Neurol Neurosurg Psychiatry 77 (2006)

441

442

443

444

445

446

447

448

449

450

451

452

453

454

455

456

457

458

459

460

461

462 1025-1029

[12] The Committee of Japan Diabetes Society on the diagnostic criteria of diabetes mellitus, Report of the Committee on the classification and diagnostic criteria of diabetes mellitus. $\mathbf{J}$ Jpn Diabetes Soc 53 (2010) 450-467.

[13] L. Kruglyak, M.J. Daly, M.P. Reeve-Daly, E.S. Lander, Parametric and nonparametric linkage analysis: a unified multipoint approach. Am J Hum Genet 58 (1996) 1347-1363

[14] S. Aerts, D. Lambrechts, S. Maity, P. Van Loo, B. Coessens, F. De Smet, L.C. Tranchevent, B. De Moor, P. Marynen, B. Hassan, P. Carmeliet, Y. Moreau, Gene prioritization through genomic data fusion. Nat Biotechnol 24 (2006) 537-544

[15] W. Bodmer, C. Bonilla, Common and rare variants in multifactorial susceptibility to common diseases. Nat Genet 40 (2008) 695-701

[16] S. Ellard, C. Bellanne-Chantelot, A.T. Hattersley, Best practice guidelines for the molecular genetic diagnosis of maturity-onset diabetes of the young Diabetologia 51 (2008) 546-553.

[17] S. Yamada, H. Nishigori, H. Onda, T. Utsugi, T. Yanagawa, T. Maruyama, K. Onigata, K. Nagashima, R. Nagai, A. Morikawa, T. Takeuchi, J. Takeda, Identification of mutations in the hepatocyte nuclear factor (HNF)-1 alpha gene in Japanese subjects with IDDM. Diabetes 46 (1997) 1643-1647

[18] Q. Zhu, K. Yamagata, A. Miura, N. Shihara, Y. Horikawa, J. Takeda, J. Miyagawa, Y. Matsuzawa, T130I mutation in HNF-4alpha gene is a loss-of-function mutation in hepatocytes and is associated with late-onset Type 2 diabetes mellitus in Japanese subjects. Diabetologia 46 (2003) 567-573 
463

464

465

466

467

468

469

470

471

472

473

474

475

476

477

478

479

480

481

482

483

484

485

486

[19] J. Grimsby, J.W. Coffey, M.T. Dvorozniak, J. Magram, G. Li, F.M. Matschinsky, C. Shiota, S. Kaur, M.A. Magnuson, J.F. Grippo, Characterization of glucokinase regulatory protein-deficient mice. J Biol Chem 275 (2000) 7826-7831

[20] E.D. Slosberg, U.J. Desai, B. Fanelli, I. St Denny, S. Connelly, M. Kaleko, B.R. Boettcher, S.L. Caplan, Treatment of type 2 diabetes by adenoviral-mediated overexpression of the glucokinase regulatory protein. Diabetes 50 (2001) 1813-1820

[21] K. Duda, Y.I. Chi, S.E. Shoelson, Structural basis for HNF-4alpha activation by ligand and coactivator binding. J Biol Chem 279 (2004) 23311-23316

[22] T. Yorifuji, K. Nagashima, K. Kurokawa, M. Kawai, M. Oishi, Y. Akazawa, M. Hosokawa, Y. Yamada, N. Inagaki, T. Nakahata, The C42R mutation in the Kir6.2 (KCNJ11) gene as a cause of transient neonatal diabetes, childhood diabetes, or later-onset, apparently type 2 diabetes mellitus. J Clin Endocrinol Metab 90 (2005) 3174-3178

[23] T. Sparso, G. Andersen, T. Nielsen, K.S. Burgdorf, A.P. Gjesing, A.L. Nielsen, A. Albrechtsen, S.S. Rasmussen, T. Jorgensen, K. Borch-Johnsen, A. Sandbaek, T. Lauritzen, S. Madsbad, T. Hansen, O. Pedersen, The GCKR rs780094 polymorphism is associated with elevated fasting serum triacylglycerol, reduced fasting and OGTT-related insulinaemia, and reduced risk of type 2 diabetes. Diabetologia 51 (2008) 70-75

[24] M. Vaxillaire, C. Cavalcanti-Proenca, A. Dechaume, J. Tichet, M. Marre, B. Balkau, P. Froguel, The common P446L polymorphism in GCKR inversely modulates fasting glucose and triglyceride levels and reduces type 2 diabetes risk in the DESIR prospective general French population. Diabetes 57 (2008) 2253-2257

[25] M. Orho-Melander, O. Melander, C. Guiducci, P. Perez-Martinez, D. Corella, C. Roos, R. Tewhey, M.J. Rieder, J. Hall, G. Abecasis, E.S. Tai, C. Welch, D.K. Arnett, V. Lyssenko, E. Lindholm, R. Saxena, P.I. de Bakker, N. Burtt, B.F. Voight, J.N. Hirschhorn, K.L. Tucker, T. 
487

488

489

490

491

492

493

494

495

496

497

498

499

500

501

502

503

504

505

506

507

508

509

510

Hedner, T. Tuomi, B. Isomaa, K.F. Eriksson, M.R. Taskinen, B. Wahlstrand, T.E. Hughes, L.D. Parnell, C.Q. Lai, G. Berglund, L. Peltonen, E. Vartiainen, P. Jousilahti, A.S. Havulinna, V. Salomaa, P. Nilsson, L. Groop, D. Altshuler, J.M. Ordovas, S. Kathiresan, Common missense variant in the glucokinase regulatory protein gene is associated with increased plasma triglyceride and C-reactive protein but lower fasting glucose concentrations. Diabetes 57 (2008) 3112-3121

[26] Q. Qi, Y. Wu, H. Li, R.J. Loos, F.B. Hu, L. Sun, L. Lu, A. Pan, C. Liu, H. Wu, L. Chen, Z. Yu, X. Lin, Association of GCKR rs780094, alone or in combination with GCK rs1799884, with type 2 diabetes and related traits in a Han Chinese population. Diabetologia 52 (2009) 834-843.

[27] F. Takeuchi, T. Katsuya, S. Chakrewarthy, K. Yamamoto, A. Fujioka, M. Serizawa, T. Fujisawa, E. Nakashima, K. Ohnaka, H. Ikegami, T. Sugiyama, T. Nabika, A. Kasturiratne, S. Yamaguchi, S. Kono, R. Takayanagi, Y. Yamori, S. Kobayashi, T. Ogihara, A. de Silva, R. Wickremasinghe, N. Kato, Common variants at the GCK, GCKR, G6PC2-ABCB11 and MTNR1B loci are associated with fasting glucose in two Asian populations. Diabetologia 53 (2010) 299-308.

[28] R. Saxena, M.F. Hivert, C. Langenberg, T. Tanaka, J.S. Pankow, P. Vollenweider, V. Lyssenko, N. Bouatia-Naji, J. Dupuis, A.U. Jackson, W.H. Kao, M. Li, N.L. Glazer, A.K. Manning, J. Luan, H.M. Stringham, I. Prokopenko, T. Johnson, N. Grarup, T.W. Boesgaard, C. Lecoeur, P. Shrader, J. O'Connell, E. Ingelsson, D.J. Couper, K. Rice, K. Song, C.H. Andreasen, C. Dina, A. Kottgen, O. Le Bacquer, F. Pattou, J. Taneera, V. Steinthorsdottir, D. Rybin, K. Ardlie, M. Sampson, L. Qi, M. van Hoek, M.N. Weedon, Y.S. Aulchenko, B.F. Voight, H. Grallert, B. Balkau, R.N. Bergman, S.J. Bielinski, A. Bonnefond, L.L. Bonnycastle, K. Borch-Johnsen, Y. Bottcher, E. Brunner, T.A. Buchanan, S.J. Bumpstead, C. 
511 Cavalcanti-Proenca, G. Charpentier, Y.D. Chen, P.S. Chines, F.S. Collins, M. Cornelis, J.C. G,

Goodarzi, J. Graessler, A. Hingorani, B. Isomaa, T. Jorgensen, M. Kivimaki, P. Kovacs, K.

Krohn, M. Kumari, T. Lauritzen, C. Levy-Marchal, V. Mayor, J.B. McAteer, D. Meyre, B.D.

Mitchell, K.L. Mohlke, M.A. Morken, N. Narisu, C.N. Palmer, R. Pakyz, L. Pascoe, F. Payne,

D. Pearson, W. Rathmann, A. Sandbaek, A.A. Sayer, L.J. Scott, S.J. Sharp, E. Sijbrands, A.

Zeggini, J.H. Zhao, T. Illig, H.E. Wichmann, J.F. Wilson, C. van Duijn, F.B. Hu, A.D. Morris,

T.M. Frayling, A.T. Hattersley, U. Thorsteinsdottir, K. Stefansson, P. Nilsson, A.C. Syvanen,

A.R. Shuldiner, M. Walker, S.R. Bornstein, P. Schwarz, G.H. Williams, D.M. Nathan, J.

D. Altshuler, B.M. Psaty, J.I. Rotter, E. Boerwinkle, T. Hansen, O. Pedersen, J.C. Florez, M.I.

McCarthy, M. Boehnke, I. Barroso, R. Sladek, P. Froguel, J.B. Meigs, L. Groop, N.J.

Wareham, R.M. Watanabe, Genetic variation in GIPR influences the glucose and insulin responses to an oral glucose challenge. Nat Genet 42 (2010) 142-148

[29] J. Dupuis, C. Langenberg, I. Prokopenko, R. Saxena, N. Soranzo, A.U. Jackson, E.

Wheeler, N.L. Glazer, N. Bouatia-Naji, A.L. Gloyn, C.M. Lindgren, R. Magi, A.P. Morris, J.

Randall, T. Johnson, P. Elliott, D. Rybin, G. Thorleifsson, V. Steinthorsdottir, P. Henneman, H.

530 Grallert, A. Dehghan, J.J. Hottenga, C.S. Franklin, P. Navarro, K. Song, A. Goel, J.R. Perry, J.M. Egan, T. Lajunen, N. Grarup, T. Sparso, A. Doney, B.F. Voight, H.M. Stringham, M. Li, 
J.P. Beilby, Y. Ben-Shlomo, R. Benediktsson, A.J. Bennett, S. Bergmann, M. Bochud, E. Boerwinkle, A. Bonnefond, L.L. Bonnycastle, K. Borch-Johnsen, Y. Bottcher, E. Brunner, S.J. Bumpstead, G. Charpentier, Y.D. Chen, P. Chines, R. Clarke, L.J. Coin, M.N. Cooper, M. Cornelis, G. Crawford, L. Crisponi, I.N. Day, E.J. de Geus, J. Delplanque, C. Dina, M.R. Erdos, A.C. Fedson, A. Fischer-Rosinsky, N.G. Forouhi, C.S. Fox, R. Frants, M.G. Franzosi, P. Galan, M.O. Goodarzi, J. Graessler, C.J. Groves, S. Grundy, R. Gwilliam, U. Gyllensten, S. Hadjadj, G. Hallmans, N. Hammond, X. Han, A.L. Hartikainen, N. Hassanali, C. Hayward, S.C. Heath, S. Hercberg, C. Herder, A.A. Hicks, D.R. Hillman, A.D. Hingorani, A. Hofman, J. Hui, J. Hung, B. Isomaa, P.R. Johnson, T. Jorgensen, A. Jula, M. Kaakinen, J. Kaprio, Y.A. Kesaniemi, M. Kivimaki, B. Knight, S. Koskinen, P. Kovacs, K.O. Kyvik, G.M. Lathrop, D.A. Lawlor, O. Le Bacquer, C. Lecoeur, Y. Li, V. Lyssenko, R. Mahley, M. Mangino, A.K. Manning, M.T. Martinez-Larrad, J.B. McAteer, L.J. McCulloch, R. McPherson, C. Meisinger, D. Melzer, D. Meyre, B.D. Mitchell, M.A. Morken, S. Mukherjee, S. Naitza, N. Narisu, M.J. Neville, B.A. Oostra, M. Orru, R. Pakyz, C.N. Palmer, G. Paolisso, C. Pattaro, D. Pearson, J.F. Peden, N.L. Pedersen, M. Perola, A.F. Pfeiffer, I. Pichler, O. Polasek, D. Posthuma, S.C. Potter, A. Pouta, M.A. Province, B.M. Psaty, W. Rathmann, N.W. Rayner, K. Rice, S. Ripatti, F. Rivadeneira, M. Roden, O. Rolandsson, A. Sandbaek, M. Sandhu, S. Sanna, A.A. Sayer, P. Scheet, L.J. Scott, U. Seedorf, S.J. Sharp, B. Shields, G. Sigurethsson, E.J. Sijbrands, A. Silveira, L. Simpson, A. Singleton, N.L. Smith, U. Sovio, A. Swift, H. Syddall, A.C. Syvanen, T. Tanaka, B. Thorand, J. Tichet, A. Tonjes, T. Tuomi, A.G. Uitterlinden, K.W. van Dijk, M. van Hoek, D. Varma, S. Visvikis-Siest, V. Vitart, N. Vogelzangs, G. Waeber, P.J. Wagner, A. Walley, G.B. Walters, K.L. Ward, H. Watkins, M.N. Weedon, S.H. Wild, G. Willemsen, J.C. Witteman, J.W. Yarnell, E. Zeggini, D. Zelenika, B. Zethelius, G. Zhai, J.H. Zhao, M.C. Zillikens, I.B. Borecki, R.J. Loos, P. Meneton, P.K. Magnusson, D.M. Nathan, G.H. Williams, 
559

560

561

562

563

564

565

566

567

568

569

570

571

572

573

574

575

576

577

578

579

580

581

582

A.T. Hattersley, K. Silander, V. Salomaa, G.D. Smith, S.R. Bornstein, P. Schwarz, J. Spranger, F. Karpe, A.R. Shuldiner, C. Cooper, G.V. Dedoussis, M. Serrano-Rios, A.D. Morris, L. Lind, L.J. Palmer, F.B. Hu, P.W. Franks, S. Ebrahim, M. Marmot, W.H. Kao, J.S. Pankow, M.J. Sampson, J. Kuusisto, M. Laakso, T. Hansen, O. Pedersen, P.P. Pramstaller, H.E. Wichmann, T. Illig, I. Rudan, A.F. Wright, M. Stumvoll, H. Campbell, J.F. Wilson, R.N. Bergman, T.A. Buchanan, F.S. Collins, K.L. Mohlke, J. Tuomilehto, T.T. Valle, D. Altshuler, J.I. Rotter, D.S. Siscovick, B.W. Penninx, D.I. Boomsma, P. Deloukas, T.D. Spector, T.M. Frayling, L. Ferrucci, A. Kong, U. Thorsteinsdottir, K. Stefansson, C.M. van Duijn, Y.S. Aulchenko, A. Cao, A. Scuteri, D. Schlessinger, M. Uda, A. Ruokonen, M.R. Jarvelin, D.M. Waterworth, P. Vollenweider, L. Peltonen, V. Mooser, G.R. Abecasis, N.J. Wareham, R. Sladek, P. Froguel, R.M. Watanabe, J.B. Meigs, L. Groop, M. Boehnke, M.I. McCarthy, J.C. Florez, I. Barroso, New genetic loci implicated in fasting glucose homeostasis and their impact on type 2 diabetes risk. Nat Genet 42 (2010) 105-116

[30] H. Onuma, Y. Tabara, R. Kawamoto, I. Shimizu, R. Kawamura, Y. Takata, W. Nishida, J.

Ohashi, T. Miki, K. Kohara, H. Makino, H. Osawa, The GCKR rs780094 polymorphism is associated with susceptibility of type 2 diabetes, reduced fasting plasma glucose levels, increased triglycerides levels and lower HOMA-IR in Japanese population J Hum Genet 55 (2010) 600-604

[31] C.T. Johansen, J. Wang, M.B. Lanktree, H. Cao, A.D. McIntyre, M.R. Ban, R.A. Martins, B.A. Kennedy, R.G. Hassell, M.E. Visser, S.M. Schwartz, B.F. Voight, R. Elosua, V. Salomaa, C.J. O'Donnell, G.M. Dallinga-Thie, S.S. Anand, S. Yusuf, M.W. Huff, S. Kathiresan, R.A. Hegele, Excess of rare variants in genes identified by genome-wide association study of hypertriglyceridemia. Nat Genet 42 (2010) 684-687

[32] B.E. Hayward, N. Dunlop, S. Intody, J.P. Leek, A.F. Markham, J.P. Warner, D.T. 
583 Bonthron, Organization of the human glucokinase regulator gene GCKR. Genomics 49 584 (1998) 137-142

585 [33] D.D. Licatalosi, R.B. Darnell, RNA processing and its regulation: global insights into 586 biological networks. Nat Rev Genet 11 (2010) 75-87

587 [34] T. Heinemeyer, E. Wingender, I. Reuter, H. Hermjakob, A.E. Kel, O.V. Kel, E.V. 588 Ignatieva, E.A. Ananko, O.A. Podkolodnaya, F.A. Kolpakov, N.L. Podkolodny, N.A. 589 Kolchanov, Databases on Transcriptional Regulation: TRANSFAC, TRRD, and COMPEL. $590 \quad$ Nucleic Acids Res 26 (1998) 364-370 
591 Table 1. Characteristics of family members and additional index cases.

\begin{tabular}{|c|c|c|c|c|c|c|c|}
\hline & ID & Current Age & Sex & BMI & $\mathrm{HbA1c}(\%)$ & $\begin{array}{l}\text { Age when } \\
\text { diagnosed } \\
\text { (Diagnosis) }\end{array}$ & Current therapy \\
\hline \multirow[t]{4}{*}{ Pedigree 1} & II-4 & 70 & $\mathrm{~F}$ & 16.2 & 5.0 & & \\
\hline & II-5 & 71 & F & 22.5 & 10.6 & $60(\mathrm{DM})$ & Insulin 66U/d \\
\hline & III-1 & 40 & F & 21.9 & 5.4 & & \\
\hline & III-2 & 37 & M & 26.0 & 6.9 & $20(\mathrm{DM})$ & Insulin \\
\hline \multirow[t]{11}{*}{ Pedigree 2} & II-1 & 79 & $\mathrm{M}$ & 19.2 & 7.5 & $50(\mathrm{DM})$ & Insulin 25U/d \\
\hline & II-2 & 77 & F & 18.6 & 5.6 & & \\
\hline & II-3 & 76 & M & 17.9 & 7.2 & $45(\mathrm{DM})$ & Insulin \\
\hline & II-5 & 74 & M & 18.2 & 6.0 & 64 (IGT) & Diet \\
\hline & II-6 & 71 & F & 18.4 & 6.6 & N/A (DM) & Oral drug \\
\hline & II-7 & 68 & $\mathrm{~F}$ & 19.9 & 5.9 & & \\
\hline & III-1 & 53 & M & 24.2 & 6.0 & 53 (IGT) & Diet \\
\hline & III-3 & 51 & M & 20.4 & 5.6 & & \\
\hline & III-4 & 47 & $\mathrm{~F}$ & 19.3 & 5.2 & & \\
\hline & III-5 & 46 & F & 19.6 & 4.9 & & \\
\hline & IV-1 & 23 & M & 19.9 & 5.6 & & \\
\hline \multirow[t]{10}{*}{ Pedigree 3} & II-7 & 92 & $\mathrm{~F}$ & 22.3 & 5.9 & & \\
\hline & III-2 & 77 & F & 23.9 & 9.3 & $30(\mathrm{DM})$ & Oral drug \\
\hline & III-5 & 72 & F & 22.0 & 8.1 & $60(\mathrm{DM})$ & Insulin $16 \mathrm{U} / \mathrm{d}$ \\
\hline & III-6 & 69 & F & 19.8 & 8.0 & $65(\mathrm{DM})$ & Insulin 16U/d \\
\hline & III-8 & 66 & $\mathrm{~F}$ & 19.1 & 6.5 & 64 (IGT) & Diet \\
\hline & III-10 & 59 & F & 19.3 & 10.2 & $57(\mathrm{DM})$ & Oral drug \\
\hline & III-11 & 67 & $\mathrm{~F}$ & 20.4 & 6.9 & $62(\mathrm{DM})$ & Oral drug \\
\hline & III-12 & 66 & M & 21.1 & N/A & $57(\mathrm{DM})$ & Oral drug \\
\hline & III-13 & 64 & $\mathrm{~F}$ & 20.0 & 6.6 & $25(\mathrm{DM})$ & Insulin \\
\hline & III-14 & 62 & M & 20.2 & 10.3 & $50(\mathrm{DM})$ & Oral drug \\
\hline \multirow[t]{7}{*}{ Pedigree 4} & II-1 & 76 & $F$ & 28.2 & 6.7 & $60(\mathrm{DM})$ & Oral drug \\
\hline & II-2 & 73 & F & 25.1 & 6.4 & $50(\mathrm{DM})$ & Oral drug \\
\hline & II-3 & 67 & F & 19.0 & 5.5 & & \\
\hline & II-4 & 64 & M & N/A & 5.4 & & \\
\hline & III-1 & 52 & $\mathrm{~F}$ & 20.4 & 5.3 & & \\
\hline & III-2 & 50 & M & 20.8 & 6.2 & $35(\mathrm{DM})$ & Oral drug \\
\hline & 1 & 57 & M & 25.7 & 7.1 & $30(\mathrm{DM})$ & Oral drug \\
\hline \multirow{5}{*}{$\begin{array}{l}\text { Additional Index } \\
\text { Cases }\end{array}$} & 2 & 47 & F & 22.9 & 10.0 & $36(\mathrm{DM})$ & Insulin 20U/d \\
\hline & 3 & 68 & $\mathrm{~F}$ & 19.7 & 7.1 & $45(\mathrm{DM})$ & Insulin 19U/d \\
\hline & 4 & 60 & F & 24.7 & 10.4 & $40(\mathrm{DM})$ & Insulin 51U/d \\
\hline & 5 & 60 & $\mathrm{~F}$ & 28.0 & 9.7 & $50(\mathrm{DM})$ & Insulin 8U/d \\
\hline & 6 & 54 & F & 34.5 & 9.1 & $40(\mathrm{DM})$ & Insulin \\
\hline
\end{tabular}

BMI: Body Mass Index, DM: Diabetes Mellitus, IGT: Impaired Glucose Toleance 
Table 2. Mutations and common nucleotide changes in exons and the promoter of GCKR in 9 index cases in families and in 18 controls. 593

\begin{tabular}{|c|c|c|c|c|c|c|c|c|c|}
\hline \multirow[b]{3}{*}{ Position } & \multirow[b]{3}{*}{ Change } & \multirow[b]{3}{*}{ Description } & \multirow[b]{3}{*}{ Effect } & \multicolumn{4}{|c|}{ Detected Number of Alleles } & \multirow[b]{3}{*}{$p^{\mathrm{a}}$} & \multirow{3}{*}{$\begin{array}{c}\text { Minor Allele } \\
\text { Frequency } \\
{[\mathrm{MAF}]}\end{array}$} \\
\hline & & & & \multicolumn{2}{|c|}{$\begin{array}{c}\text { Index Cases from } \\
\text { Families }(n=9)\end{array}$} & \multicolumn{2}{|c|}{ Controls $(\mathrm{n}=18)$} & & \\
\hline & & & & Major & Minor & Major & Minor & & \\
\hline \multicolumn{10}{|c|}{ Mutations (MAF<1\%) } \\
\hline Promoter & g. $-689 G>A$ & & & 17 & 1 & 36 & 0 & 0.33 & $0.000^{\mathrm{b}}$ \\
\hline Promoter & g. $-299 \mathrm{G}>\mathrm{A}$ & & & 17 & 1 & 36 & 0 & 0.33 & $0.000^{\mathrm{b}}$ \\
\hline Total & & & & 15 & 3 & 36 & 0 & 0.033 & \\
\hline \multicolumn{10}{|c|}{ Common changes } \\
\hline Promoter & $\begin{array}{c}\text { g.-959 } \\
\text { insAATGTTG }\end{array}$ & & & 16 & 2 & 33 & 3 & 1.00 & $\mathrm{~N} / \mathrm{D}$ \\
\hline Exon 2 & g. $468 \mathrm{G}>\mathrm{A}$ & Synonymous & E66E & 17 & 1 & 35 & 1 & 1.00 & N/D \\
\hline Exon 3 & g. $671 \mathrm{~A}>\mathrm{G}$ & Missense & $\mathrm{E} 77 \mathrm{G}$ & 17 & 1 & 33 & 3 & 1.00 & $0.024^{\mathrm{c}}$ \\
\hline Exon 11 & g. $9709 \mathrm{G}>\mathrm{A}$ & Noncoding exon & & 17 & 1 & 33 & 3 & 1.00 & $0.123^{c}$ \\
\hline Exon 14 & g. $11169 \mathrm{~T}>\mathrm{C}$ & Missense & L446P & 8 & 10 & 25 & 11 & 0.087 & $0.467^{\mathrm{c}}$ \\
\hline
\end{tabular}

594 GenBank Accession No. NT 022184.15

$595 \quad{ }^{a}$ Fisher exact test. ${ }^{b}$ Frequency in 105 normoglycemic controls. ${ }^{c}$ Frequency in HapMap-JPT. 


\section{Figure Captions}

598

599 Figure 1. Four pedigrees with familial aggregated diabetes mellitus.

600

601 Figure 2. Multipoint HLOD and LOD scores in genome-wide linkage analysis for 4 pedigrees.

602

603 Figure 3. Multipoint HLOD and LOD scores in fine mapping of D2S168-D2S2259 and D7S640-D7S636.

604

605 Figure 4. Haplotype analysis in the D2S168-D2S2259 region and the GCKR g. 6859C >G genotype for pedigree 3.

606 
Figure 1.
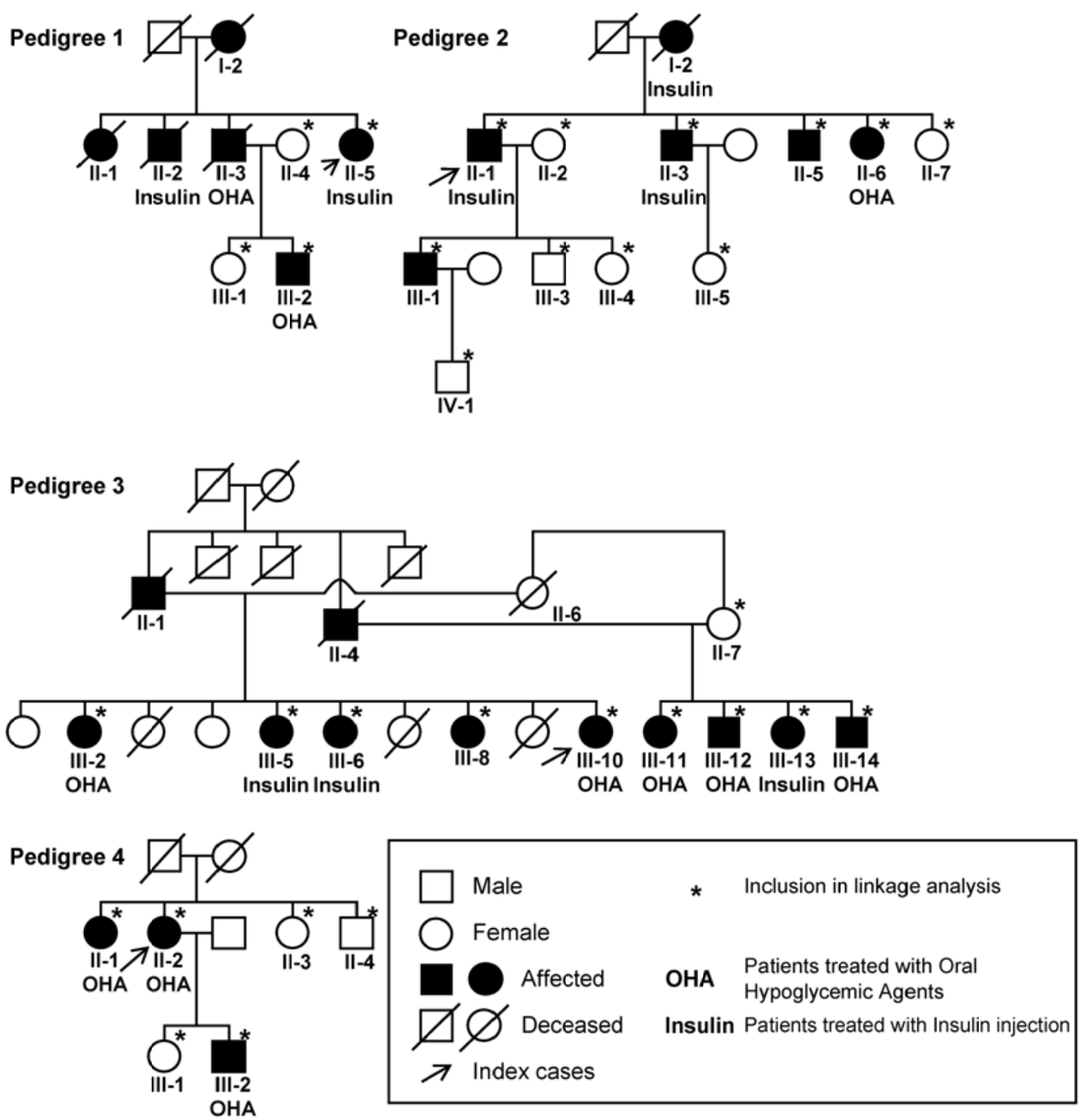


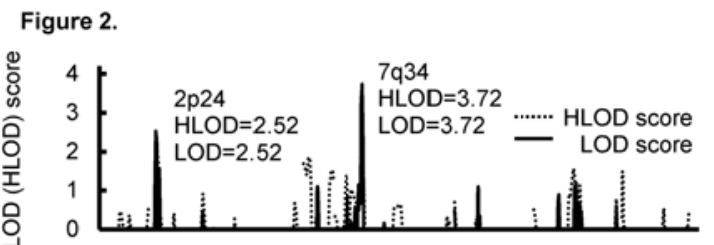


Figure 3.

Chromosome 2

(11-43Mb) ….... HLOD score

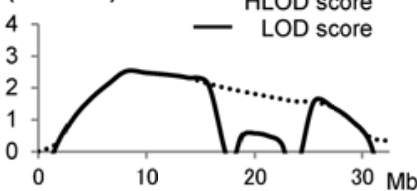

Chromosome 7

(133-151Mb)

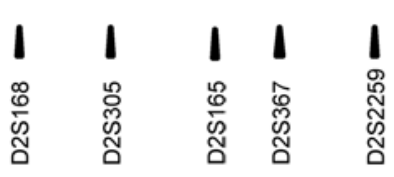

1

Chromosome 2

(11-43Mb)

Fine Mapping
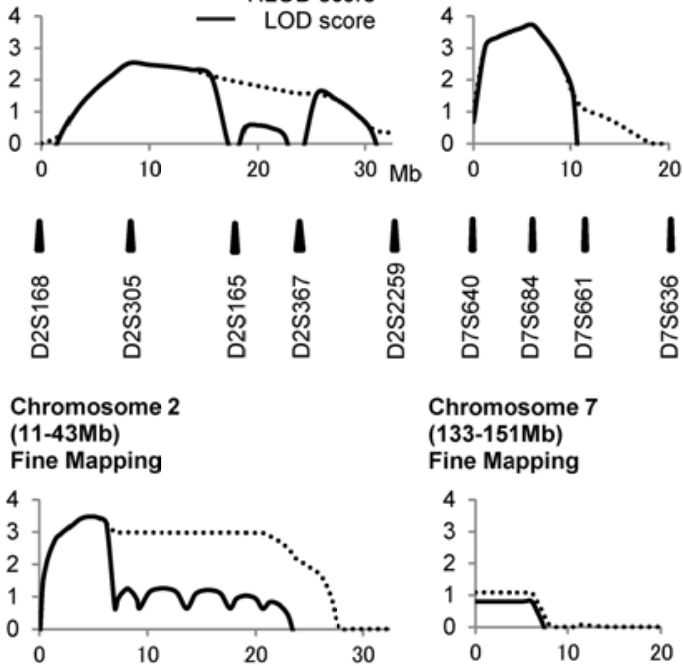

III III | | | ||| | || |||

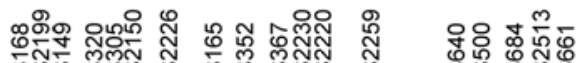

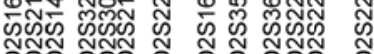

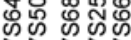


Figure 4.

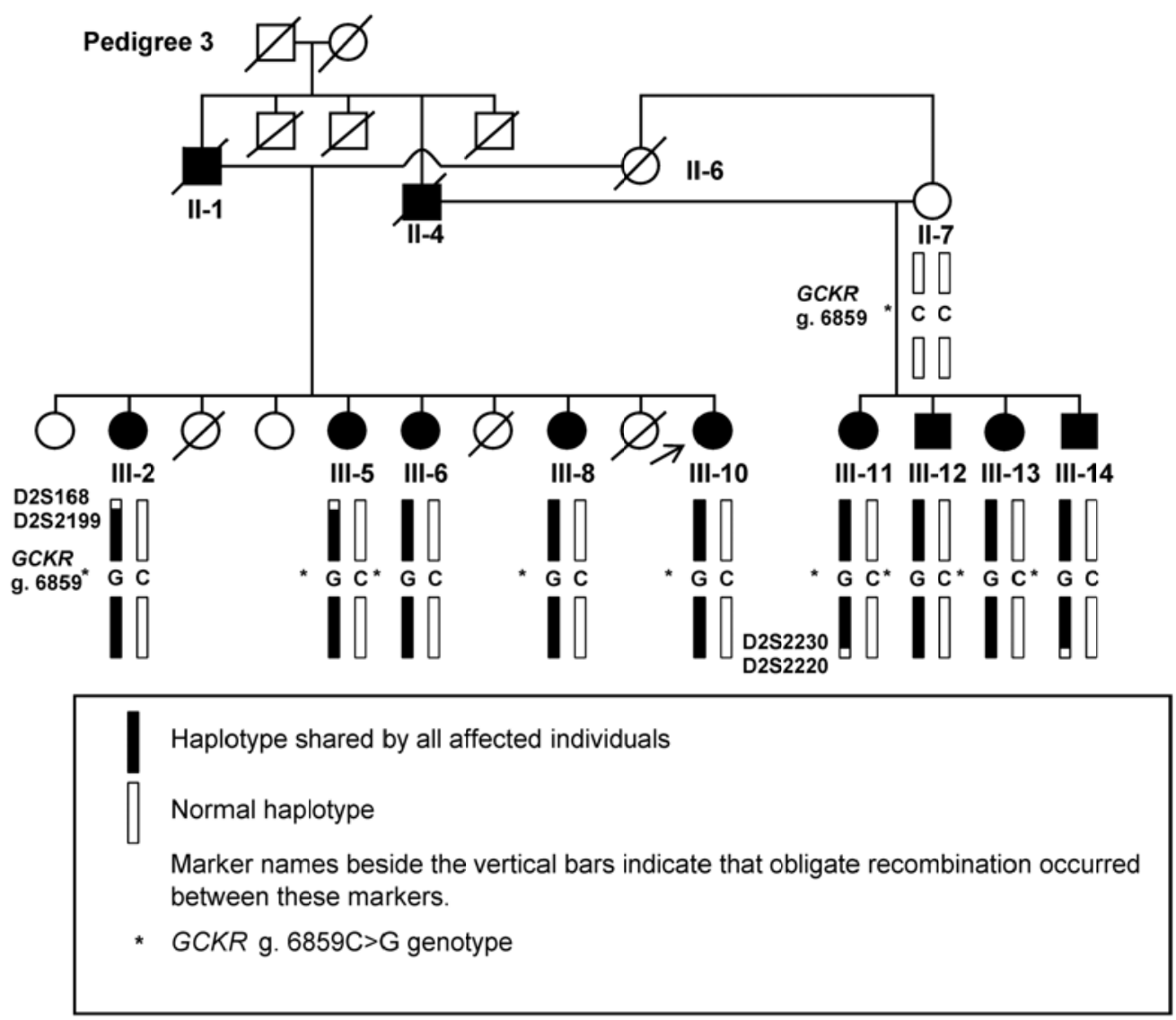


Supplementary Table 1. Genes that are highly prioritized in the linkage region using Endeavour.

\begin{tabular}{llll}
\hline Rank & Symbol & Description & Known metabolic function \\
\hline 1 & GCKR & Glucokinase regulatory protein & \\
\hline 2 & NCOA1 & Nuclear receptor coactivator 1 & \\
\hline 3 & FOSL2 & Fos-related antigen 2 & Lipid Metabolism $^{\text {a }}$ \\
\hline 4 & APOB & Apolipoprotein B-100 precursor & \\
\hline 5 & MYCN & N-myc proto-oncogene protein & Purine Metabolism $^{\text {a }}$ \\
\hline 6 & RBKS & Ribokinase & \\
\hline 8 & XDH & Xanthine dehydrogenase/oxidase & \\
\hline 9 & KHK & Ketohexokinase & \\
\hline 10 & CADP & Nuclear receptor-binding protein & Glutamine-dependent carbamoyl-phosphate synthase, \\
& & Aspartate carbamoyltransferase, Dihydroorotase & \\
\hline 11 & RDH14 & Retinol dehydrogenase &
\end{tabular}

${ }^{\mathrm{a}}$ Excluded from candidate genes 
Supplementary Table 2. Sequencing Primers for GCKR

GCKR
\begin{tabular}{|l|l|l|l|}
\hline & Forward & & Reverse \\
\hline promoter1a & TGACTAGCTGTGGTTGACCCT & promoter1b & ATCTCCCTCACTCTCTCCCCT \\
\hline promoter2a & CCCCATCCCTTATCCCTTCT & promoter2b & TGGACAAATTGGGACTCACA \\
\hline promoter3a & GGGTTGTTGTGAGGCTCAAAT & promoter3b & TCCGGGGTCTCAATGACAT \\
\hline $1 \mathrm{a}$ & TAGTGACCAGGAAAGGGTGGT & $1 \mathrm{~b}$ & CCAAAAGGGAGAAAGGAGAA \\
\hline $1 \mathrm{c}$ & TAATATGCCCAGAGCACCAA & & \\
\hline $2 \mathrm{a}$ & AGCAAGACATGGGAGTCAAA & $2 \mathrm{~b}$ & TGAGGGAATAAGGAATGGTGA \\
\hline $3 \mathrm{a}$ & AATGTAGCCTGCCCTAATACG & $3 \mathrm{~b}$ & CCTTCTAGCACCGATCTCATT \\
\hline $4 \mathrm{a}$ & TTCTGATGCACTTGAGCCTT & $4 \mathrm{~b}$ & TTATAAGCTTAGGGGCACCC \\
\hline $5 \mathrm{a}$ & ACCTCAATCCCAATGCAGTCT & $5 \mathrm{~b}$ & TAATCCCAGCTACTCCGCAGA \\
\hline $5 \mathrm{c}$ & AGAGCGTTGAATAGCCATTG & & \\
\hline $6 \mathrm{a}$ & TGGTACTATCACATGCATGCC & $6 \mathrm{~b}$ & TGGTGGGCTGCAGTCTTACT \\
\hline $7 \mathrm{a}$ & TAAGGGAGCTGTGCCTTCA & $7 \mathrm{~b}$ & TTCCAATGAACTTCCCACCT \\
\hline & & $7 \mathrm{c}$ & TTAGATAGGGAAGGTGGGACA \\
\hline $8 \mathrm{a}$ & AGTGTTAGATCTCCTCCACGG & $8 \mathrm{~b}$ & AGGGTCAGAGAGGTCTCCAAA \\
\hline $9 \mathrm{a}$ & ATTTAAACGCTGGGCTGCT & $9 \mathrm{~b}$ & AGAAGCACACAGAAAAGGCA \\
\hline $10 \mathrm{a}$ & ATCCCAGCCTCTCACTCTCAT & $10 \mathrm{~b}$ & CCACTGAGCTTTGTAAACCCA \\
\hline $11 \mathrm{a}$ & TGAACTTAAGTGATCTGCCCA & $11 \mathrm{~b}$ & AGGGATGCCAGTATAAGGCTT \\
\hline
\end{tabular}


Supplementary Table 3. Characteristics of normoglycemic controls.

\begin{tabular}{lccc}
\hline & & $\begin{array}{c}\text { Subjects for sequencing } \\
(\mathrm{n}=18)\end{array}$ & $\begin{array}{c}\text { Subjects for genotyping SNPs } \\
(\mathrm{n}=105)\end{array}$ \\
\hline \multirow{2}{*}{ Men } & Number & 10 & 52 \\
& Age (y: mean \pm SD) & $64.0 \pm 4.4$ & $68.3 \pm 8.1$ \\
& BMI (mean \pm SD) & $22.6 \pm 2.0$ & $22.5 \pm 2.6$ \\
& Fasting Plasma Glucose (mmol/l: mean \pm SD) & $4.86 \pm 0.21$ & $4.74 \pm 0.31$ \\
& HbA1c (\%: mean \pm SD) & $5.64 \pm 0.12$ & $5.45 \pm 0.17$ \\
\hline Women & Number & 8 & 53 \\
& Age (y: mean \pm SD) & $61.1 \pm 6.1$ & $66.5 \pm 8.3$ \\
& BMI (mean \pm SD) & $21.4 \pm 2.3$ & $21.7 \pm 2.8$ \\
& Fasting Plasma Glucose (mmol/l: mean \pm SD) & $4.66 \pm 0.29$ & $4.68 \pm 0.38$
\end{tabular}

SD: Standard deviation. 
Supplementary Table 4. Missense SNPs of MODY genes in 10 index cases.

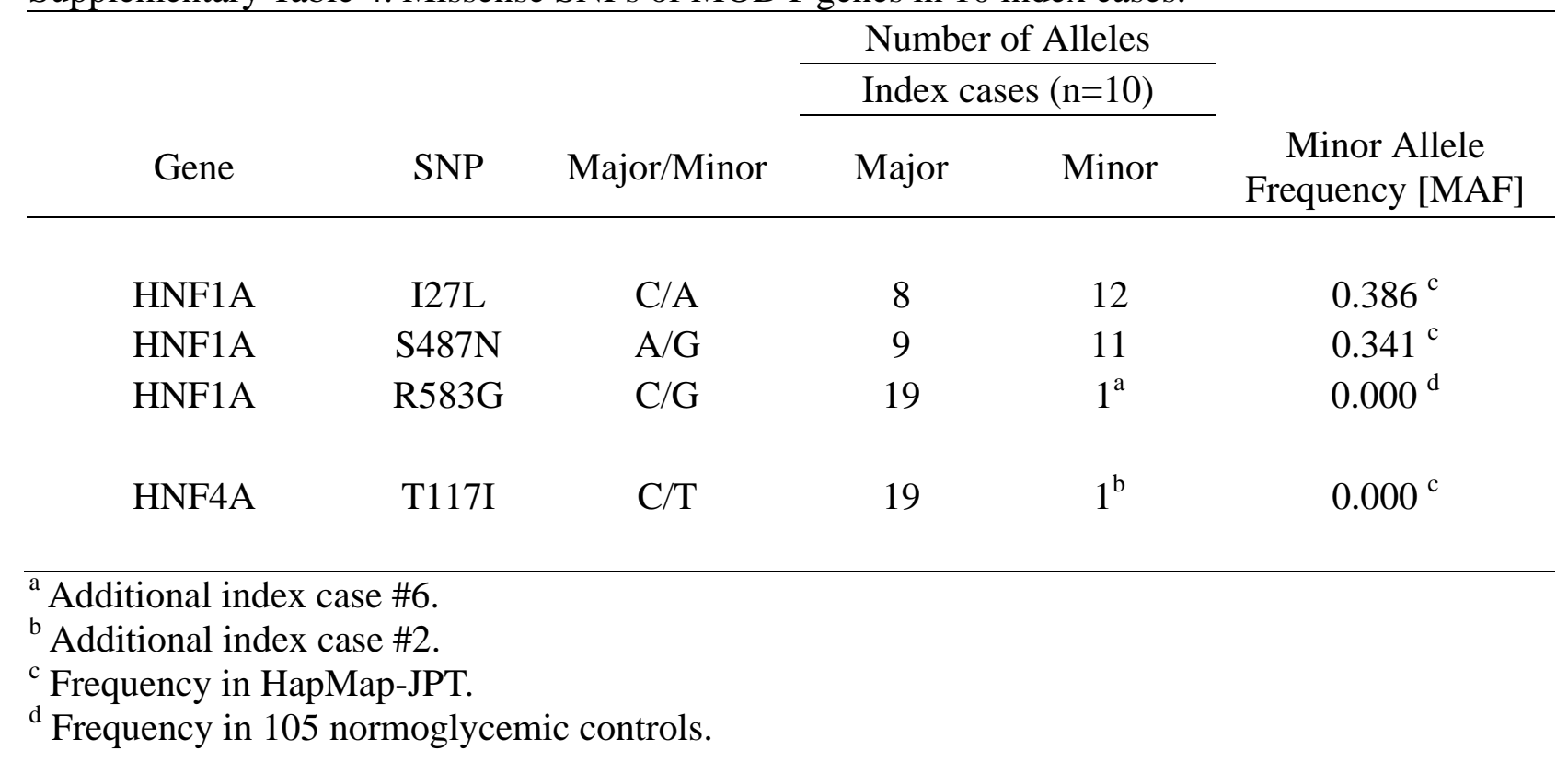


Supplementary Table 5. Nucleotide changes in coding exons of 7 genes in the linkage region in index cases from 4 families.

\begin{tabular}{|c|c|c|c|c|c|}
\hline \multirow[b]{3}{*}{ Gene } & \multirow[b]{3}{*}{ SNP } & \multirow[b]{3}{*}{ Major/Minor } & \multirow{2}{*}{\multicolumn{2}{|c|}{$\begin{array}{l}\text { Number of Alleles } \\
\text { Index cases }(n=4)\end{array}$}} & \multirow[b]{3}{*}{$\begin{array}{c}\text { Minor Allele } \\
\text { Frequency }[\mathrm{MAF}]\end{array}$} \\
\hline & & & & & \\
\hline & & & Major & Minor & \\
\hline NCOA1 & P504P & $\mathrm{A} / \mathrm{T}$ & 7 & 1 & $0.307^{\mathrm{a}}$ \\
\hline FOSL2 & $\mathrm{R} 198 \mathrm{H}$ & $\mathrm{G} / \mathrm{A}$ & 7 & 1 & $0.004^{b}$ \\
\hline KHK & V49I & G/A & 5 & 3 & $0.166^{\mathrm{a}}$ \\
\hline
\end{tabular}

\footnotetext{
${ }^{a}$ Frequency in HapMap-JPT.

${ }^{\mathrm{b}}$ Frequency in 105 normoglycemic controls.
} 
Supplementary Figure 1. Pedigrees of Additional Index Cases

Index Case 1

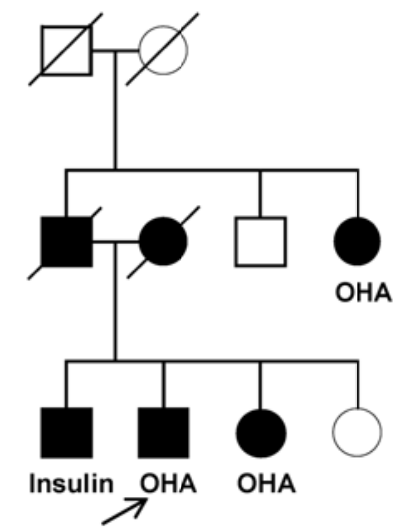

Index Case 4
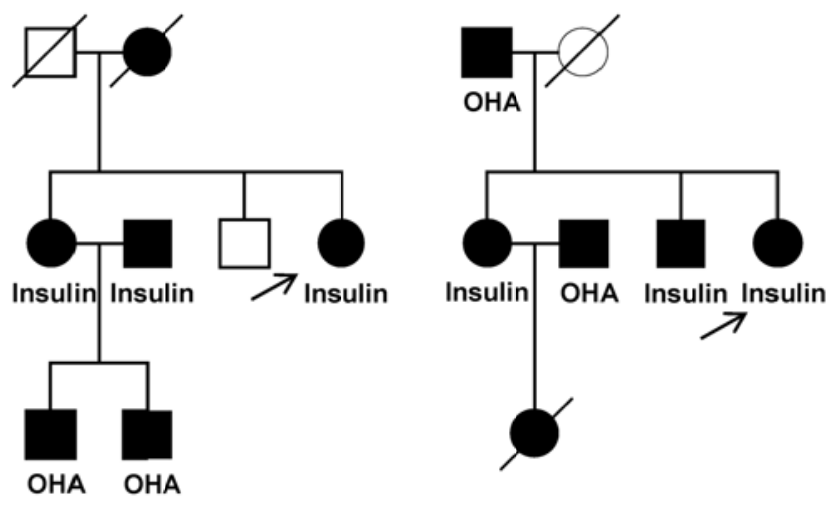

Index Case 5

OHA

Patients treated with Oral Hypoglycemic Agents

Insulin Patients treated with Insulin injection
Index Case 6

Index Case 3
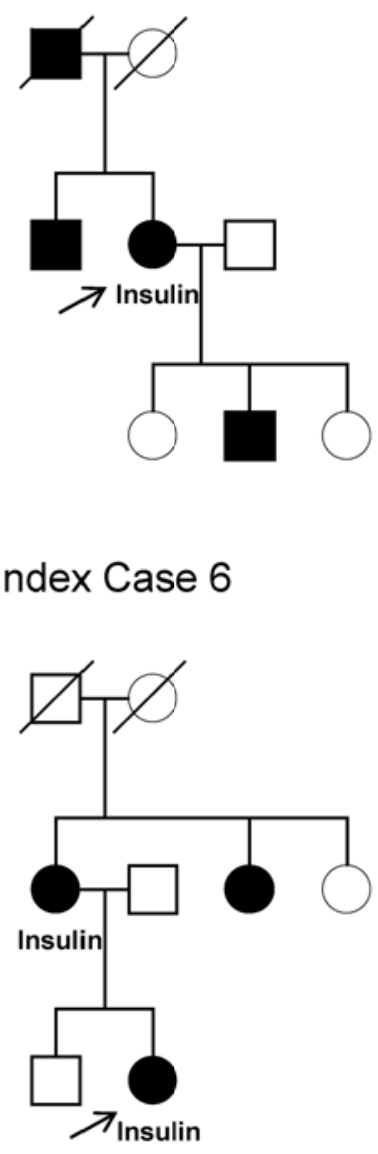